\title{
URGENT ISSUES OF ORGANIZATION OF AUDIT ACTIVITY IN UKRAINE AND DIRECTIONS FOR THEIR SOLUTIONS
}

\author{
Maryna Shendryhorenko', Liubov Shevchenko \\ Donetsk National University of Economics and Trade named after Mykhailo Tugan-Baranovsky, Ukraine
}

\begin{abstract}
In conditions of economic uncertainty and competition, the importance of objective economic control increases both from owners and supervisors. Reliable financial reporting provides the possibility of making conscious economic decisions, warns of operations associated with increased risk. The opinion of the auditor increases the trust in the financial activity of the company and the general loyalty to business by the stakeholders - owners, investors, potential customers, suppliers, authorities. Therefore, the issue of the exclusion of the corruption component between the audit firm and the client company during the organization and conduct of the audit is a topical issue in many countries of the world, including Ukraine. The purpose of the paper is to substantiate the theoretical principles and practical recommendations for the organization of audit activity and overcoming corruption in the economic sphere in Ukraine. Methodology. The methodological basis of research is general scientific and special methods of knowledge. To determine the current state of audit in Ukraine, quantitative changes in the dynamics of audit firms and certified auditors, applied methods of synthesis, comparison, grouping. For isolating problems that arise in the market of audit services, methods of specificity and abstraction are used. The method of analysis was the basis for determining the main factors of corruption in the audit sector and its impact on the dynamics of Ukraine's economic development. The dialectical method, synthesis, and abstraction have been used to formulate proposals for improving the order, in which services are provided in the audit field. A tabular method was used to reflect the systematic results of the consolidation and grouping of indexes of corruption perception index in Ukraine in 2013-2017. The graphical method was used to visually reproduce the dynamics of the change in the perceptions of corruption in Ukraine, the USA and Poland in 2013-2017, and the changes in the number of audit firms and certified auditors in Ukraine in 2012-2016. Results. The results of the study substantiated the need to improve the legislative and regulatory framework that regulates audit activity. The main factors that negatively influence the audit activity and contribute to the development of corruption in Ukraine are identified. The proposals on improvement of the situation in the market of audit services, as well as increase of efficiency of auditors' activity are given. Practical implications. The pragmatic value of the research results is the possibility of their use for developing strategic measures to improve the audit activity in Ukraine, bringing the quality of domestic audit closer to the level of audit in EU countries. Value/originality. It is proposed to implement a set of legislative and regulatory changes to improve the organization and implementation of audit practices in Ukraine to minimize the corruption component in order to ensure the transparency of the audit process.
\end{abstract}

Key words: audit, audit activity, control, corruption, economy.

JEL Classification: M42, L84, O44

\section{Introduction}

Corruption constrains economic development, weakens democratic institutions and the principles of law, violates public order, and destroys public confidence, thereby contributing to the rampancy of the organized crime and other negative phenomena. The annual volume of bribes in the world economy is estimated at one trillion US dollars. The world economy loses another 2.6 trillion US dollars due to corrupt activities. Those funds represent more than five percent of the global gross domestic product (GDP). According to the United Nations Development Program, in the developing countries, corruption-related losses exceed 10 times the official development assistance (State Audit Service of Ukraine, 2017).

Corresponding author:

${ }^{1}$ Department of Accounting and Audit, Donetsk National University of Economics and Trade named after Mykhailo Tugan-Baranovsky. E-mail: shendrigorenko@donnuet.edu.ua

${ }^{2}$ Department of Accounting and Audit, Donetsk National University of Economics and Trade named after Mykhailo Tugan-Baranovsky.

E-mail: shevchenko@donnuet.edu.ua 
At present, the size of the shadow economy in Ukraine exceeds 33\% of the official GDP (Ministry of Economic Development and Trade of Ukraine, 2017). Analysing the situation, one can come to the conclusion that corruption in Ukraine affects all the state bodies, including those that are called to fight it: courts, prosecutors, other law enforcement agencies, etc.

A significant problem of the modern economy as regards to the legal field is the identification of trends in the development of the independent external audit. After the most high-profile corruption scandals involving leading audit firms over the last 10 years, the issue of bringing to justice the auditors who mistakenly or deliberately delivered positive audit opinions where that should not have been done has become relevantly poignant. That being the case, the main protective argument of the management of audit firms is that at the time of rendering its services, a respective firm positioned itself as an audit one (by its nature and qualification), while in the event of liability under the audit contract that firm presented itself as a consulting one ostensibly providing only consultancy services.

The financial crisis has revealed weak points in various sectors of the economy. In particular, audit scholars and practitioners have not yet given a reasoned answer to the following question: Why is there in the statistics of bankrupt business entities a substantial share of companies that enjoyed a positive audit opinion of their performance? The answer to that question and suggestions how to deal with such a problem are presented in the current study.

The main objective of the study conducted was to substantiate the theoretical principles and practical recommendations for organizing the audit activity and overcoming corruption in the economic sphere of Ukraine.

A relevant scientific research involves the following tasks: an analysis of the current state of external audit and the facts of corruption schemes in the economy sectors; the identification of the main issues affecting the quality of audits and being the result of fraud on the part of the management of companies; formulating suggestions for the improvement of the audit activity organization to prevent corruption schemes from coming into being.

The scientific novelty of this study is the identification of the main factors of the negative impact of corruption on the economy and the substantiation of proposals to improve the quality and efficiency of the audit activity in Ukraine.

\section{The current state of corruption in Ukraine}

The state and efficiency of the economic environment in Ukraine are determined by a number of positive and negative trends. The level of corruption and the shadow economy in Ukraine is one of the factors that have a direct negative impact on the efficient functioning of the economic and social sphere, on the level of investment attractiveness of Ukraine and its competitiveness as an entity of international relations.

In order to understand the degree of impact of the level of corruption and the efficiency of anticorruption policies in Ukraine, let us analyse the dynamics of change in the Corruption Perceptions Index in Ukraine over five years (Table 1, Figure 1).

Table 1

\section{Corruption Perceptions Index in Ukraine}

\begin{tabular}{|l|c|c|c|c|c|}
\hline \multirow{2}{*}{ Indices } & \multicolumn{5}{|c|}{ Value by years } \\
\cline { 2 - 6 } & 2013 & 2014 & 2015 & 2016 & 2017 \\
\hline $\begin{array}{l}\text { Corruption } \\
\text { Perceptions Index }\end{array}$ & 25 & 26 & 27 & 29 & 30 \\
\hline
\end{tabular}

Source: compiled by the authors on the basis of a generalization of data of the international organization "Transparency International" for the period from 2013 until 2017

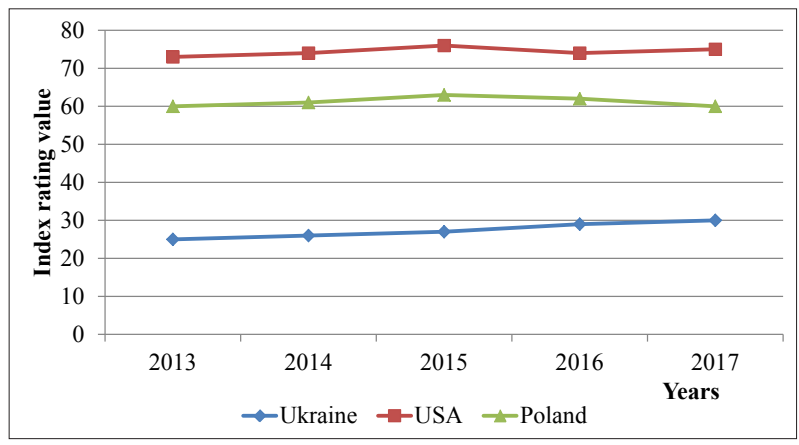

Fig. 1. Dynamics of change in the Corruption Perceptions Index in Ukraine, the USA, and Poland from 2013 until 2017

Source: compiled by the authors on the basis of a generalization of data of the international organization "Transparency International" for the period from 2013 until 2017

When analysing the data obtained, it can be concluded that the level of perception of corruption and combating it in Ukraine over the five years has been at a fairly low level, with a slight upward trend.

The existence of a "developed corruption network" in Ukraine at the level of small, medium, and large businesses can be explained by the relevant factors, the most important of which is the fact that the large businesses are owned by the so-called oligarchic clans that are interested in the submission and disclosure of "their own reliable" information about the financial and property situation of the companies under their control. According to the estimates by the NGO "Institute of Social and Economic Transformation", due to the introduction of various corruption schemes, Ukraine's budgetary shortfall stands at more than 180 billion UAH per year (Institute of Social and Economic Transformation, 2017).

That figure looks quite impressive in the context of the hybrid war, which Ukraine has been forced to wage for more than three years now. After all, those funds, even in 
spite of the low institutional capacity of the State bodies, could contribute to strengthening the country's defence capability, restoring its infrastructure potential, and improving the level of public education and healthcare.

\section{Negative experience of audit companies' activities in Ukraine}

One of the ways for reducing corruption in the private sector and in the field of financial services is to organize and ensure efficient audit work. Independent audit as an individual economic phenomenon has already existed in Ukraine for almost 25 years. During that period, an independent audit has proved to be an objective tool for controlling the activities of companies belonging to the private sector. Still, it is impossible to deny the existence of facts of corruption in the activities of audit firms.

A vivid example of that phenomenon was the incident involving a famous audit firm, a member of the Big Four, i.e. PricewaterhouseCoopers, which became the most high-profile development in the audit industry in 2017: the National Bank of Ukraine (NBU) strokes PricewaterhouseCoopers (audit) LLC (Kyiv), a Ukrainian subsidiary of $\mathrm{PwC}$, off the register of audit firms that have the right to conduct bank audits. The decision was made by the Board of the National Bank on the basis of a submission by the NBU Committee on Bank Audit. A report says that the reason for that decision was the ungrounded confirmation by PricewaterhouseCoopers (audit) LLC of inaccurate information regarding financial and business activities of the PJSC CB "PrivatBank" (Kyiv), in particular, regarding the latter's size of credit risk and regulatory capital (Interfax-Ukraine News Agency, 2017).

"The findings of the PricewaterhouseCoopers (audit) did not reflect the genuine risks of PrivatBank's operations, which led to the adjudication of that financial institution as insolvent, its nationalization and substantial expenditure by the State on its capitalization," the National Bank of Ukraine press release says (Interfax-Ukraine News Agency, 2017).

Another example is the BDO LLC (a Ukrainian subsidiary of BDO International Limited), which was struck off the register of audit firms that have the right to conduct audits of banks, due to a scandal with inaccurate information regarding financial and economic activities of PJSC “Diamantbank”, PJSC "Bank for Investments and Savings", and PJSC "CB "GLOBUS" for the year 2015.

As stated in the official press release of the NBU dated August 11, 2016, "The National Bank of Ukraine has for the second year in a row revealed a number of irregularities in the operations of the audit firm that were related to the company's improper performance of its duties as an auditor. Thus, as a result of the analysis of the relevant audit findings, the regulator has disclosed the facts that evidence the confirmation by the BDO LLC of inaccurate information contained in the annual financial statements of some banks for the year 2015. What is more, in contravention of the requirements of Article 70 of the Law of Ukraine "On Banks and Banking Activity", BDO LLC did not notify the NBU in writing of the misstatements in financial reporting, irregularities and deficiencies in the operation of the Bank, including significant losses of regulatory capital, that had been disclosed during the audit and rendering other audit services and that could lead to the Bank's insolvency" (Internet portal about finance and economics "Finbalance", 2016).

However, BDO LLC managed to prove their noninvolvement and win an appeal against the NBU's decision thereby regaining the right to conduct bank audits.

The Oratania LLC audit firm was also struck off the register of audit firms that have the right to carry out bank audits followed by its complete striking off the register of audit firms. It was noted that the National Bank of Ukraine had disclosed a number of irregularities in the operation of that audit firm that were related to the company's improper performance of its duties as an auditor. An important fact is that that audit company audited financial statements of the PJSC CB "PrivatBank" in the period from 2007 until 2009 (The National Bank of Ukraine, 2016).

It can, therefore, be concluded that a corrupt element in the general "audit company-client" arrangement does indeed exist in Ukraine, but the aspect of factual corroboration of that kind of corruption, gathering evidence base against it and public condemnation of that corruption, remain fairly problematic. In general, proving and public disclosure of corrupt schemes practiced by audit firms operating in Ukraine are to a large extent isolated.

\section{Problematic aspects of the audit firms' activities in Ukraine}

In our opinion, the existence of a corruption precedent in the activities of audit firms in Ukraine is due to a number of factors of economic and non-economic nature.

One of the factors contributing to the increase in the likelihood of "corrupt" cooperation between auditors and their customers, i.e. consumers of audit services, is the tendency towards the reduction of the number of certified auditors.

According to the statistical reporting data of the Audit Chamber of Ukraine (ACU), in the period from 2012 until 2016, there was a negative tendency towards the reduction of the number of persons who were certified auditors (Audit Chamber of Ukraine, 2016).

The general dynamics of the number of audit firms and certified auditors is shown in Fig. 2. 


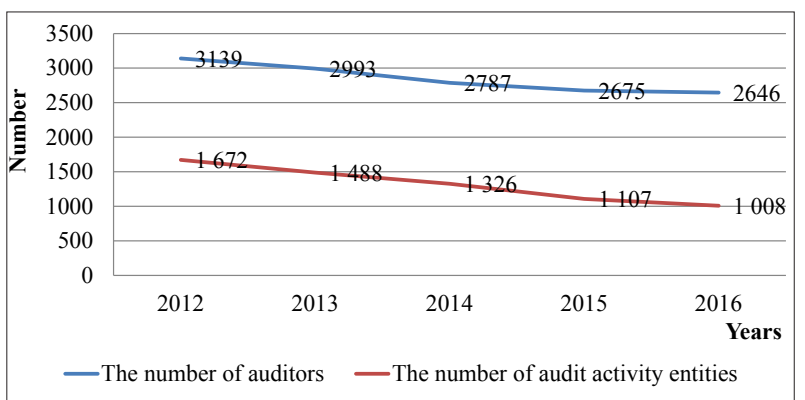

Fig. 2. Dynamics of the number of audit firms and certified auditors in Ukraine from 2012 until 2016

Source: compiled by the authors on the basis of a generalization of data of the Audit Chamber of Ukraine (Audit Chamber of Ukraine, 2016)

Thus, in the period from 2012 until 2016, the share of certified auditors decreased by 493 persons in absolute terms and by $15.71 \%$ in relative terms.

It should be noted that in the period from 2013 until 2015 , the reduction of the share of certified auditors in Ukraine was caused by the significant influence of the political factor, viz. the annexation of the Crimean peninsula and the beginning of hostilities in the East of the country that led to the emergence of some areas in the Donetsk and Luhansk regions that are temporarily beyond the government control. It was in the period between 2013 and 2014 that the number of certified auditors decreased by 206 persons.

The conduct of hostilities in the East of the country, the illegal annexation of the Crimean peninsula, the unfavourable economic situation, the intensification and the uncontrollable nature of inflationary processes and, as a result, an accelerated depreciation of the national currency, all contributed to the formation of the second factor for the increase of corruption in the economic sphere, i.e. the reduction of the number of audit firms.

According to the data of the Audit Chamber of Ukraine, the largest decrease in the number of audit activity entities took place in the Donetsk (43.8\%), Luhansk (38.5\%), and Ternopil (33.3\%) regions. A significant decrease in the number of audit entities was observed in the Rivne (26.3\%), Zakarpattia (21.4\%), and IvanoFrankivsk (20\%) regions (Audit Chamber of Ukraine, 2016). The decrease in the number of auditors in the Western regions of Ukraine was caused by a growing number of bankrupt companies, the aggravation of migration processes, etc.

On the whole, the tendencies towards a reduction in the number of audit firms and certified auditors contribute to limiting the supply of audit services and ones associated therewith, as well as to strengthening the process of the market monopolization.

The shrinking of the audit services market in Ukraine contributes to the intensification of corrupt practices in the country's economy. It is our opinion that due to the increased risk of loss of potential clients, with which the audit firms formed close professional relationships, the said firms apply not only measures of marketing and flexible pricing policy but, in some cases, they may also conduct an audit whereby their client company would obtain the "desired" results. Apart from that, prerequisites emerge for the auditor to obtain an additional income for "loyalty".

According to the data of the Audit Chamber of Ukraine, as for the year 2016, audit services were provided for the total amount of $1,973,102.3$ thousand UAH. Of that sum, the share of the city of Kyiv and the Kyiv Region is $1,634,543.8$ thousand UAH, which is $82.8 \%$ of the total amount of services rendered in 2016. So, the rest of the regions of Ukraine provided audit services for $338,558.5$ thousand $\mathrm{UAH}$, which is $17.2 \%$ of the total amount of services rendered in 2016. That being the case, the average cost of one order in Ukraine ranges from 9,600 UAH (Mykolaiv region) to 90,800 UAH (the city of Kyiv and the Kyiv Region) (Audit Chamber of Ukraine, 2016).

Taking that into account, it is quite clear that audit firms and individual auditors can enter into illicit corrupt schemes or be their direct initiators for the purpose of illegal enrichment.

\section{Conclusions of the study}

Despite the complexity of the economic and political situation, in order to successfully combat various kinds of corruption schemes in the field of audit services, it is necessary to develop a full range of administrative and legal measures.

Having analysed the negative factors contributing to the development of corruption processes in the audit activity, and the findings of the research conducted, we consider it expedient to suggest the following:

1. The inclusion of a representative of the National Anti-Corruption Bureau of Ukraine (NABU) into the governing body of the Audit Chamber of Ukraine. The inclusion of a NABU representative into the governing body of the Audit Chamber of Ukraine will promote cooperation in the anti-corruption struggle, the promptitude in detecting corruption and examining cases regarding auditors who violate the principles of the Code of Professional Ethics. At the same time, in order to avoid corruption precedents, we propose a systematic rotation of the representative of the NABU in the governing body of the Audit Chamber of Ukraine, the rotation period presumed to be six months.

2. Developing a State system of material incentives for individuals and corporate entities to make them point out the facts of corruption during an audit while preserving the informer's anonymity.

3. Establishing at the legislative level a procedure whereby the mandatory change of the audit company by the client company is effected once every three years. 
4. The imposition of an "interest on corruption", i.e. all losses incurred by the State or natural persons and corporate entities due to the concealment or incorrect submission of information in the auditor's report, should be paid by the audit firm in question.

5. Introducing and making public on a mandatory basis of declarations of property status and personal income for auditors, heads of audit firms, and their immediate families. At the same time, we propose to envisage administrative and criminal responsibility for not submitting or distorting information in the above declarations.

6. Creating an analogue of the ProZorro system for audit firms. We suggest introducing the following mechanism for the functioning of a similar electronic system: audit firms should hand over to the Audit Chamber of Ukraine the lists of services they can provide, the official number of auditors who are authorized to conduct audits, and the price lists of their services. At the ACU, the information gathered would be processed, sorted, and a general list of all audit firms would be compiled. That being the case, it is important that neither the State nor the system administrator could influence the participants in the procedure and sift them out in any way. An audit service client would $\log$ on to the ACU website and file an application, which should indicate the type of services that must be performed by a potential service provider, as well as the amount of payment for the services rendered. After that, the electronic system, based on the criteria entered and using the "random" principle, selects an audit firm for the client company. The main advantages of this solution are that the State is in a position to monitor the real situation on the market of audit services, and at the same time, the possibility of a "prior coordination" of the audit results is ruled out.

7. Introduction of amendments and supplements to the Law of Ukraine "On Auditing Activity" and the International Standards on Auditing, in particular, to ISA 240 "The Auditor's Responsibilities Relating to Fraud in an Audit of Financial Statements", where Article 7 says: "Two types of intentional misstatements are relevant to the auditor - misstatements resulting from fraudulent financial reporting and misstatements resulting from misappropriation of assets" (The International Federation of Accountants, 2012). Audit standards prescribe that the theft of assets and misstatements that affect the financial position of the company while ignoring the impact of corruption should be taken into account. The insufficient accuracy of standards in that part has been and will be the cause of many corporate scandals related to the auditor's findings, on account of which the professional opinion of that auditor may be called into question.

The above suggestions and areas of improvement of audit activity in Ukraine should also be strengthened by the support on the part of the State: legislative stability of the legal and regulatory framework should be ensured as should be the promotion of the accountability of national audit firms as regards the market of audit services.

\section{References:}

Audit Chamber of Ukraine (2016) Generalized information on the state of audit activity in Ukraine in 2016. Retrieved from: http://apu.com.ua/1064-zvit-do-kmu-2016 (accessed 24 February 2018)

Institute of Social and Economic Transformation (2017) Eight tax-evasion schemes: The offshore companies and shadow importers are the most tax underpayments. Retrieved September 7, 2017 from: http://iset-ua.org/ua/novini/ podatki/item/116-visim-skhem-ukhylennia-vid-podatkiv

Interfax-Ukraine News Agency (2017) The NBU has excluded PwC from the register of bank auditors for an untrustworthy audit of PrivatBank. Retrieved July 20, 2017 from: http://ua.interfax.com.ua/news/general/437466. html

Internet portal about finance and economics «Finbalance» (2016) The BDO auditors confirmed inaccurate information in the banks' reporting. Retrieved August 11, 2016 from: http://finbalance.com.ua/news/NBU-auditoriBDO-pidtverdzhuvali-nedostovirnu-informatsiyu-u-zvitnosti-bankiv

Ministry of Economic Development and Trade of Ukraine (2017) Trends of the shadow economy in Ukraine in January-September 2017. Retrieved from: http://www.me.gov.ua/Documents/List?lang=uk-UA\&id=e384c5a76533-4ab6-b56f-50e5243eb15a\&tag=TendentsiiTinovoiEkonomiki (accessed 12 February 2018)

State Audit Service of Ukraine (2017) Preventing Corruption. Retrieved December 8, 2017 from: http://www.dkrs. gov.ua/kru/uk/publish/article/136627

The International Federation of Accountants (2012) International Standard on Auditing 240, The Auditor's Responsibilities Relating to Fraud in an Audit of Financial Statements. Retrieved from: http://www.apu.com.ua/1038mizhnarodni-standarti-kontrolyu-yakosti-auditu-oglyadu-inshogo-nadannya-vpevnenosti-ta-suputnikh-poslugvidannya-2015-roku (accessed 20 February 2018)

The National Bank of Ukraine (2016) BDO Ltd is excluded from the Register of Audit Firms, which have the right to conduct audits of banks. Retrieved August 11, 2016 from: https://bank.gov.ua/control/uk/publish/article?art_ $\mathrm{id}=35066885$

Transparency International (2018) Corruption Perceptions Index 2013-2017. Retrieved February 22, 2018 from: https://ti-ukraine.org/research/indeks-koruptsiyi-cpi-2017/ 